\title{
Status of Financial Inclusion in India, Persisting Challenges and Way Forward
}

\author{
Namita Swain, Ajay Jain
}

\begin{abstract}
Financial inclusion is a critical pillar of development and has been a major policy thrust for the Indian Government over the decades. However some of the major policy impetuses were received the last one decade resulting in some of the biggest policy interventions for financial inclusion in the world. Pradhan Mantri Jan Dhan Yojana, Direct Benefit Transfer under Digital Banking and Aadhar has been significant interventions in this area. Despite these and several areas policy measures as well as technological innovations adopted by RBI and banking sector, even though encouraging, is much less than satisfactory when it comes to their extent and penetration when it comes to usage by marginalized sections, people in the informal economy and those living in remote areas. The significant barriers for achieving inclusive growth are Financial illiteracy, lack of convenience, technology issues and viability. This study aims at integrating some of the results of existing literature on financial inclusion and role played by Government, RBI and the other banks in promoting inclusive growth. It also attempts to analyze the key persisting challenges on the demand as well as supply aspects of financial inclusion. On the basis of its findings the paper proposes a set of preliminary recommendations to strengthen and support financial inclusion in India. It has been observed that the financial sector has still not been able to design appropriate products in a sustainable way that can address the needs of the poor, those who are in the informal economy or to identify key gaps in a huge and diverse country like India where social security is very low for most of population. Technology obviously is playing and still needs to play a far greater role in addressing some of these challenges which the traditional banking models have failed to address.
\end{abstract}

Keywords : Financial Inclusion; Inclusive Growth; RBI ; Banks; Policy; Technology; Jan Dhan Yojana; Direct Benefit Transfer.

\section{INTRODUCTION}

The Rangarajan Committee constituted by Government of India on Financial Inclusion defines financial inclusion as the process of ensuring access to financial services and timely and adequate credit where needed by vulnerable groups such as the weaker sections and low income groups at an affordable cost . Financial inclusion is not only critical for the Individuals and households for the host of banking services that provides like saving, access to credit, integration with more formal financial system, insurance and others; it is also critical for the country and the banks alike for it plays a huge role in improving social security with improved savings and coverage through insurance, in promoting entrepreneurship

Revised Manuscript Received on September 25, 2019

Namita Swain, Research Scholar, SRMIST, India.

Dr Ajay Jain, Assistant Professor, SRMIST, India. and job creation as well as reduce vulnerability and improves financial shock abortion capacity among families. The other major benefit in the context of a country like India where corruption is a major issue in Governance is that by financial inclusion and by mechanism such as Direct Benefit Transfer (DBT), corruption and leakages can be reduced to a significant level.

Financial inclusion in the Indian context is all the more critical given the large poor population who do not have adequate social security, the large young population primarily employed in the informal sector who can benefit from entrepreneurship and job creation though financial investments, low penetration of banking and insurance services, direct transfer as a mean to reach beneficiaries of welfare schemes younger population, large poor populations,

\section{OBJECTIVE}

- To study various policies taken up by Government of India and the RBI to promote financial inclusion

- To assess the results of the above policies and the current status of financial inclusion in India

- To take a critical look at various persisting changes for true financial inclusion and suggest a set of measures going forward.

\section{METHODOLOGY}

This study is descriptive in nature and is based on secondary data and sourced from the different periodic publications of government and private organizations such as the data from various ministry websites, data from RBI, NABARD, World Bank as well as studies done by private agencies such as CRISIL, Standard and Poor. Wherever necessary, expert opinions as covered by various media sources have also been considered to arrive at a more nuanced view in the analysis and recommendation section.

\section{DISCUSSION AND ANALYSIS}

\section{Policy Initiatives for Financial Inclusion}

Since Independence, several attempts have been made towards upliftment of poor through financial inclusion, particularly with a focus on rural areas where most of the population without banking services lives. It can be said that the first attempts at financial inclusion were made with the Nationalization of banks in 1969 and 1980, after which a slew of measures were taken to bring about financial inclusion which include the cooperative movement, followed by priority sector lending, lead bank scheme in the year 1969 , introduction of regional rural banks in the year 1975, creation of National Bank for Agriculture and

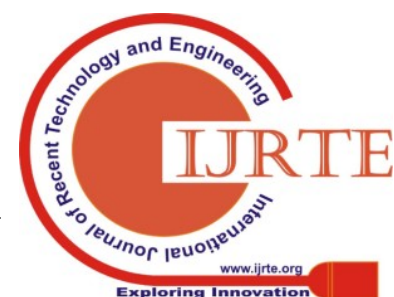


Rural development in the year 1982,service area approach in the year 1989, microfinance, kisan credit cards etc. However the real emphasis on financial inclusion came when Reserve Bank of India's Rangarajan Committee Recommendations was introduced in 2008. Subsequent to which RBI started to raise regular concerns regarding financial exclusion and urged banks to put special emphasis on this aspect especially at the rural hinterland. The following are some of the major phase wise initiatives pushed by the RBI over the years ${ }^{1}$ :

i) Phase I (2010-2013): In April 2010, RBI asked all the banks to submit 3 year plan for financial inclusion approved by the Board. As a cosequence total of 74,414 villages with population more than 2000 were identified and banking outlets were opened which included 2493 bank branches, 69589 Business correspondents (BC) and 2332 by other modes such as ATM centres and Mobile vans etc .

ii) Phase II (2013-2016): In phase II a total of 452151 villages with population less than 2000 were given banking services through a variety of means.

iii) Phase III (2016-2019): A number of measures were taken to encourage bank linkage at the individual household levels. These include measures such as Aadhar (UIDAI), Direct Benefit Transfer (DBT) and Jan Dhan Yojana (JDY), apart from a host of measures to improve efficiency in the banking system such as adoption of financial technology driven measures with focus on cashless transactions ex. BHIM app etc. Given the fact that most of the financial inclusion discussion centers around Aadhar, Direct Benefit Transfer and Pradhan Mantri Jan Dhan Yojana, each of the initiatives are described in some detail below -

Aadhaar - Unique Identification Authority of India (UIDAI): The government of India started the drive to provide a unique individual identification number to every individual in India in the year 2009. To fulfill this purpose, GOI established the Unique Identification Authority of India (UIDAI), which issued a Aadhaar card having a Aadhaar number to each and every Indian citizen. $85 \%$ of India's populations were enrolled in Aadhaar as of March 2017. More than 400 million bank accounts were linked to Aadhaar as of April 2017 and 6 million-bank accounts opened by e-KYC(Know your costomer). As a result, it reduces the number of people who have not opened bank accounts due to lack of legal documents ${ }^{2}$.

Direct Benefit Transfer: Both state and central governments have launched various social protection programmes in the form of food subsidy by Public Distribution System (PDS), employment guarantee by Mahatma Gandhi National Rural Employment Scheme (MGNRES), LPG Subsidy, Old Age pensions and scholarship etc directly in the bank account of the beneficiary. The government of India has introduced Direct Benefit Transfer for preventing financial leakages in the form of intermediaries, fake beneficiaries, and delayed payment. Currently 35 Government schemes are linked with DBT. Rs.22006 Crore DBT payments sent using Aadhaar payment Bridge System in the financial year $2016-17^{3}$.

Pradhan Mantri Jan Dhan Yojana (PMJDY): This scheme was launched in 2014 and between 2014 and 2018, a total of
34 crores bank accounts have been opened to link so far excluded households with the financial system. Some of the specific features in PMJDY include - Zero balance accounts, relaxed KYC norms, Direct transfer of Government subsidies to accounts reducing delays and leakages, accidental coverage of 2 lakhs and life insurance cover of Rs 3lakh. PMJDY is one of the biggest public interventions for financial inclusion in India.

\section{ROGRESS MADE UNDER FINANCIAL INCLUSION INITIATIVES}

India has made serious progress at least in the aspect of providing bank linkage to a huge population compared to earlier year. The RBI annual report 2016-17 states the following

\begin{tabular}{|c|c|c|c|c|}
\hline Parameters & $\begin{array}{l}\text { As of } \\
\text { Marc } \\
\text { h } 2010\end{array}$ & $\begin{array}{l}\text { As of } \\
\text { March } \\
2016\end{array}$ & $\begin{array}{l}\text { As of } \\
\text { March } \\
2017\end{array}$ & $\begin{array}{l}\text { Growth } \\
\text { since } \\
2010 \text { in } \\
\%\end{array}$ \\
\hline $\begin{array}{l}\text { Total No of } \\
\text { Bank branches } \\
\text { in } \\
\text { Villages/rural } \\
\text { areas }\end{array}$ & 33,378 & 51,830 & 50,860 & \\
\hline $\begin{array}{l}\text { Total no of } \\
\text { Business } \\
\text { Correspondent } \\
\text { s (BCs) } \\
\end{array}$ & 34,174 & 531,229 & 543,472 & \\
\hline $\begin{array}{l}\text { No of } \text { Basic } \\
\text { Saving Bank } \\
\text { Deposit } \\
\text { Accounts } \\
\text { (BSBDA) - in } \\
\text { Millions } \\
\end{array}$ & 73 & 469 & 533 & \\
\hline $\begin{array}{l}\text { Deposits in } \\
\text { BSBDA - in } \\
\text { INR billions }\end{array}$ & 55 & 636 & 977 & \\
\hline
\end{tabular}

The following data represents progress made under Pradhan Mantri Jan Dhan Yojana (PMJDY) unto 31st March 2019.

\begin{tabular}{|l|l|l|l|}
\hline Banks & $\begin{array}{l}\text { No } \\
\text { accounts } \\
\text { opened }\end{array}$ & $\begin{array}{l}\text { Deposits } \\
\text { in Lacs }\end{array}$ & $\begin{array}{l}\text { No of RuPay } \\
\text { debit cards } \\
\text { issued }\end{array}$ \\
\hline $\begin{array}{l}\text { Public } \\
\text { Sector } \\
\text { Banks }\end{array}$ & 280361546 & 2669682.80 & 228959558 \\
\hline $\begin{array}{l}\text { Regional } \\
\text { Rural Banks }\end{array}$ & 59893689 & 1659074.40 & 38590690 \\
\hline $\begin{array}{l}\text { Private } \\
\text { Sector } \\
\text { Banks }\end{array}$ & 12406995 & 281977.90 & 11558715 \\
\hline Total & $\mathbf{3 5 2 6 6 2 2 3 0}$ & $\mathbf{9 6 1 0 7 3 5 . 1 0}$ & $\mathbf{2 7 9 1 0 8 9 3 6}$ \\
\hline Source: http://pmjdy.gov.in/ \\
\hline
\end{tabular}


The following presents a more detailed description of progress made under various initiatives ${ }^{4}$ -

\begin{tabular}{|l|l|l|l|}
\hline Particulars & $\begin{array}{l}\text { Year } \\
\text { Ended } \\
\text { March } \\
\mathbf{2 0 1 0}\end{array}$ & $\begin{array}{l}\text { Year Ended } \\
\text { 2016 }\end{array}$ & $\begin{array}{l}\text { Year ended } \\
\text { March } \\
\mathbf{2 0 1 7}\end{array}$ \\
\hline Banking Outlets in Rural locations - Branches & 33,378 & 51,830 & 50,860 \\
\hline Banking Outlets in Villages>2000-BCs & 8,390 & 98,958 & 105,402 \\
\hline Banking Outlets in Villages<2000- BCs & 25,784 & 432,271 & 438,070 \\
\hline Total Banking Outlets in Villages - BCs & 34,174 & 531,229 & 543,472 \\
\hline Banking Outlets in Villages- Other Modes & 142 & 3,248 & 3,761 \\
\hline Banking Outlets in Villages -Total & $\mathbf{6 7 , 6 9 4}$ & $\mathbf{5 8 6 , 3 0 7}$ & $\mathbf{5 9 8 , 0 9 3}$ \\
\hline Urban Locations covered through BCs & 447 & 102,552 & 102,865 \\
\hline BSBDA-Through branches (No. in millions) & 60 & 238 & 254 \\
\hline BSBDA-Through branches( Amt. in billions) & 44 & 474 & 691 \\
\hline BSBDA-Through BCs (No. in millions) & 13 & 231 & 280 \\
\hline BSBDA-Through BCs (Amt. in billions) & 11 & 164 & 285 \\
\hline BSBDA-Total (No. in millions) & 73 & 469 & 533 \\
\hline BSBDA Total (Amt. in billions) & 55 & 638 & 977 \\
\hline OD facility availed in BSBDAs (No. in & 0.2 & 9 & 9 \\
\hline OD facility availed in BSBDAs (Amt. in & 0.1 & 29 & 17 \\
\hline KCCs -Total (No. in millions) & 24 & 47 & 46 \\
\hline KCCs -Total (Amt. in billion) & 1,240 & 5,131 & 5,805 \\
\hline GCC-Total (No. in millions) & 1 & 11 & 13 \\
\hline GCC-Total (Amt. in billions) & 35 & 1,493 & 2,117 \\
\hline ICT A/Cs-BC-Total Transactions (No. in millions) & 27 & 827 & 1,159 \\
\hline $\begin{array}{l}\text { ICT A/Cs-BC-Total Transactions (Amt. in } \\
\text { billions) }\end{array}$ & 7 & 1,687 & 2,652 \\
\hline
\end{tabular}

Global financial inclusion measurement indices such as the World Banks's Global Findex database (GFX) of April 2018 states that almost $80 \%$ adult Indians are now bank linked compared to only $40 \%$ in 2011 . India also has made serious progress compared to other countries as per the report. India's GFX was recored 35 in 2011 which increased to 53 in 2014 , and further increased to 80 in 2017. There is a speedy improvement in FI, showing that relevant Indian policies in the last few years have worked well . GFX 2017 stands at 80 for China (79 in 2014), 76 for Russia, 70 for Brazil, 69 for South Africa, 96 for UK, and 93 for US. Inspite the constraints of poverty, illiteracy, and lack of spread of banking network in India the progress under PMJDY is laudable.

\section{PERSISTING CONCERNS}

Multiple research on financial inclusion confirms the tremendous progress made by India in providing bank linkage to its vast population. However several concerns persist. A few notables one are below-

1) Geographic disparity in credit penetration: India's first FI index CRISIL Inclusix 2018, while confirming the rapid progress made under financial inclusive initiatives, also notes the disparity that exists in several aspects especially in the credit penetration aspect. The report notes "despite an overall improvement in scores, a wide disparity between the bottom 50 and top 50 districts, remains on credit penetration. The disparity is more pronounced in the eastern regions and north-eastern regions of the country. The overall score for credit penetration stood at 56 ; for the east it was $42.5 ; 47.7$ for the North-East; and for the north it was 44.8. The west and south were better off with scores of 91.6 and 59.1.

2) High proportion of non-operational bank accounts: The world Bank Global findex database 2018, mentions that less than $1 \%$ of PMJDY account holders (3.1 million beneficiaries) use overdraft facilities available to them, and $17 \%$ of PMJDY accounts are "zero-balance" means no transaction has taken place in those accounts till date .

3) Gender disparity in Bank linkage: While overall $80 \%$ people in India have bank accounts, $83 \%$ men have accounts compared to $77 \%$ of females.

4) Low credit penetration: The International Monetary Fund (IMF) notes that only 13 per cent of Indian borrow through formal channels with proper documentation. Despite so many priority sector lending rules prevails in India, hardly 35 per cent of Indian farmers utilize institutional loans. The rest are most likely to be relying 
on alternative sources such as moneylenders paying high interest rates. This high cost of credit is a major hindrance in front of promoting entrepreneurship that can be nurtured only when bank customers can save, borrow, and remit/receive funds at low cost.

5) Lack of financial Literacy: Financial illiteracy is one of the biggest concerns regarding financial inclusion. Everyone should have knowledge about how to meaningfully take benefit of various banking services provided by the banks and other initiatives. The current financial literacy in India is very low. The next phase of Government policy focus is supposed to be high on raising financial literacy among beneficiaries. The standard and poor report on financial literacy states that almost three forth of Indian adults lack financial literacy.

6) Lack of appropriate saving and credit products: Given the diversity and variations in income levels and sources as well as consumption patterns, contextual need based financial products are required. At this moment not enough products are there that are designed keeping in view the needs of rural population.

\section{WHAT NEEDS TO BE DONE? POLICY RECOMNDATIONS}

Keeping in view the policy measures taken by the Government in last few years, the progress made and the persisting challenges in financial inclusion, the following are a set of recommendations the Government and financial institutions must keep in view going ahead to maximize the benefits of financial inclusion.

First, Banks and financial service providers must understand the needs of the beneficiaries and design appropriate products: For example, most small farmers in India have a seasonal and irregular income. Hence, come of the capital cost loans can be designed in a way to respond to the farmers' income cycle rather than the traditional monthly EMI which might not suit the income realities of the farmer. Most of the loans taken by the poor are also utilized for various consumption/ life event purpose, we still do not have enough well design financial products for such purpose with an appropriate repayment structure. This local knowledge shall only come when banks take a proactive interest in the local market rather than just opening bank branches.

Second, urgent need to improve financial literacy: Unfortunately, this is one area where India still needs to do a great deal of work. According to a Standard and Poor's survey 2015 , only $24 \%$ of Indians have financial literacy, leaving two thirds of Indians in need of this knowledge and understanding. However, the Government has been putting a lot of policy emphasis for improving financial literacy among beneficiaries. However, improving financial literacy shall take a multi-pronged effort from a lot of stakeholders i.e. Government, RBI, Banks, NGOs, educational institutions, community associations, media and financial agencies operating at the grassroots. Inability to popularize digital

banking is also due to lack of digital literacy among the users in spite of high smartphone ownership in India.

Third, need for more active partnership between the government and providers of various financial products: This would enable banks and financial firms to come up with need based products and services for rural population which might be risky initially. This would enable risks and rewards of working with marginal populations are shared between banks and the Government. A good example is rural affordable housing. The Government has announced a public private partnership policy for affordable housing in 2018 and aims at building 10 million houses by 2022. Such initiatives are required in other areas too.

Forth, there is a need to integrating indigenous financial service models into mainstream baking with adequate regulation: For example Research from Some Indigenous institutions of financial inclusion shows that Chit Fund $\mathrm{s}$ are very popular in India and spreading widely. It has the appeal of a "bottom-up" approach to financial inclusion which aims at providing financial help to low-income households to meet their financial needs. However, these institutions have so far been excluded from the formal financial sector, largely due to ignorance 5 . Very large group of people in India are participating in different forms of informal regular savings-credit settlements with each other. In this condition Chitfunds acts as an efficient circulation of money between those who want to save some parts of their money and others who want to borrow. So to complement such situation, indigenous financial institutions must find a place within the policies of financial inclusion of the government. These are the established institutions having strong social network. They have a far greater reach and acceptance amongst the people than most top-down policies of financial inclusion in the recent history of liberalized India. Government policies must recognize this and build on the strengths of indigenous financial institutions so that indigenous financial service model will be integrated with adequate regulation.

Fifth, Technology must be used to promote consumer protection and in bringing down cost of financing: This is a very critical aspect which must be gearing to bring down the operating costs of these financial instruments which are more expensive in comparison to larger ticket instruments of the prevailing financial sector. More Innovation in the financial sector through greater autonomy and competition must be encouraged. Financial Institutions should have the autonomy to experiment with all management practices as 
well as financial products which can help sustainable solutions to the financial needs of all sectors of the Indian economy.

Sixth, encouraging usage of credit for micro and small enterprise development: This will eventually help in the country's economic growth and in creation of jobs in the informal sector. The standard of living of the community at the grass-root level can be increased by boosting micro and small enterprises. Poverty alleviation can also be possible by encouraging usage of credit to micro and small enterprises. The next phase of FI is therefore less to do with policy and more to do with awareness programme in the society by educating people about dissemination of financial service and digital advancement. It is also important to make FI beneficiaries aware about the scope of expanding rural enterprises through borrowing and take responsibility to repay bank loans.

Seventh, new opportunities must be identified and products designed with help if technological innovations to expand the reach of financial inclusion: While the Government is also doing a lot to digitize payments and wages, there is still a lot of scope to further expand these services. Domestic remittances offer another huge opportunity for linking and channeling fund transfers.

\section{CONCLUSION}

Financial inclusion is the gateway to increased prosperity for all. Government $f$ Indi and the RBI though a number of policy measures have been able to improve bank linkage to a significant population, however several bottlenecks remain such initiatives can bear fruit. At the same time, innovation and technology and financial literacy are needed too to achieve the final goal. At the same time, financial inclusion is pretty much still an ongoing process in India and true transformations these measures can bring out will be visible in the next 5-10 years. It is wise to remember the old saying "we cannot change the direction of the wind but we can set the sail", the small measures played by various stakeholders in different aspects of financial inclusion shall collectively make India truly financially inclusive in coming days.

\section{REFERENCES}

1. Ananth S; Creating an Enabling Digital Ecosystem: Issues and Challenges in Financial Inclusion; IIM Bangalore, Working paper no 508, April 2016

2. Alpana Vats,"Promoting Financial Inclusion: An Analysis of the Role of Banks", Indian Journal of Social development, Vol.7, No.1, June 2007, Pp.107-126

3. Das A, Dutta T; Analyzing Data of Pradhan Mantri Jan Dhan Yojana ; IIT Bombay, Technical Report; MAY 2017

4. Gunthupalli S; Exploring the impacts of "Pradhan Mantri Jan-Dhan Yojana in urban Areas with reference to Mumbai; IOSR Journal of Economics and Finance (IOSR-JEF) 2321-5925, PP 82-86

5. Harpreet Kaur and Kawal Nain Singh; "Pradhan Mantri Jan Dhan Yojana (PMJDY): A Leap towards Financial Inclusion in India"; International Journal of Emerging Research in management and Technology; 2015

6. Kumar V, Singh D; "PMJDY: A Conceptual Analysis and Inclusive Financing" International Journal of Innovative Social Science \& Humanities Research, Volume- II, Issue-I, March 2015
7. Madav V, Kapadia S; Financial Literacy and Financial Inclusion in India; International Journal of Pure and Applied Mathematics; Volume 118 No. 18 2018, 1133-1150

8. Raihanath, Pavithran KB; Role Of Commercial Banks In The Financial Inclusion Programme; Journal of Business Management \& Social Sciences Research (JBM\&SSR)Volume 3, No.5, May 2014

9. Rajasekaran N; Including the Excluded: The Scenario of Financial Inclusion in India; IOSR Journal of Business and Managemen (IOSR-JBM), Volume 20, Issue 2. Ver. VII (February. 2018), PP 64-69

10. Ravikumar T, Assessing Role of Banking Sector in Financial Inclusion Process in India http://www.microfinancegateway.org/sites/default/files/mfg-en-paper-ass essing-role-of-banking-sector-in-financial-inclusion-process-in-india-ma y-2013.pdf accessed on 9th August 2019

11. Naik G, Singh C; inancial Inclusion after PMJDY: A Case Study of Gubbi Taluk, Tumkur; Working Paper no 568, IIM Bangalore; March 2018

12. Sami S, Iqbal B; Role of Banks in Financial Inclusion in India, Contaduría y Administración Volume 62, Issue 2, April-June 2017, Pages 644-656

13. Satpathy I, Patnaik BCM; Pradhan Mantri Jan Dhan Yojna (Pmjdy) - A New Direction for Mainstreaming the Financially Excluded; International Journal of Management; Volume 6, Issue 2, February (2015), pp. 31-42

14. Sabri T, Ananth S; Challenges to Financial Inclusion in India: The Case of Andhra Pradesh; Economic and Political Weekly; Vol. 48, Issue No. 07, 16 Feb, 2013

15. Singh R; Saving Mobilization and PMJDY in India; EPRA International journal of economic and business review; Vol-4, Issue 1, January 2016, Page 148-156

16. Thorat, U. (2006). Reading on Financial Inclusion, Indian Institute of banking and finance, New Delhi, Taxman Publications Pvt: Ltd, Pp. 261-270

17. Subba Rao K.C.K, "Financial inclusion: An Introspection", Economic Political Weekly, February 3, 2007, Pp.355-360.

18. World Bank; Making it easier to apply for a bank account: A study of the Indian Market; Policy Research Working Paper 8205; September 2017 